\title{
Upaya Guru Pendidikan Pancasila dan Kewarganegaraan dalam Mengimplementasi Pendidikan Karakter pada Siswa SMA Negeri 2 Donggo
}

\author{
Sri Rejeki' \& Bernadus Ikir Wilhem²
}

\author{
${ }^{1}$ Pendidikan Pancasila dan Kewarganegaraan, Universitas Muhammadiyah Mataram, Email: umi.cici.66@gmail.com \\ ${ }^{2}$ Pendidikan Pancasila dan Kewarganegaraan, Universitas Muhammadiyah Mataram, Email: bernadus23@gmail.com
}

\begin{abstract}
INFO ARTIKEL
Riwayat Artikel:

Diterima: $\quad$ 13-

Februari-2019

Disetujui: 25-Maret2019
\end{abstract}

\section{Kata Kunci:}

upaya

guru

mengimplementasi pendidikan

karakter

\section{ABSTRAK}

\begin{abstract}
Abstrak: Tujuan penelitian ini adalah untuk mengetahui upaya dan kendala-kendala guru pendidikan Pancasila dan Kewarganegaraan dalam mengimplementasikan pendidikan karakter pada siswa SMA Negeri 2 Donggo. Penelitian ini merupakan penelitian kualitatif dengan pendekatan deskriptif. Subyek informasi adalah guru PPKn, Kepala Sekolah, dan Siswa. Teknik pengambilan sampel menggunakan pursposif sampling. Data penelitian diperoleh melalui metode observasi, wawancara, dan dokumentasi. Jenis data berupa data kualitatif. Sumber data yaitu sumber data primer dan sekunder. Analisis data yang dipakai adalah reduksi data, penyajian data, dan verivikasi. Berdasarkan hasil penelitian dapat disimpulkan bahwa upaya guru pendidikan Pancasila dan Kewarganegaraan dalam mengimplementasikan pendidikan karakter pada siswa sudah terlaksana dengan baik. Hal ini terlihat dari pengintegrasian pendidikan karakter oleh guru dalam setiap kali pertemuan melaui mata pelajaran dan di luar mata pelajaran atau partisipasi nyata. Sedangkan kendalakendala guru pendidikan Pancasila dan Kewarganegaraan dalam mengimplementasikan pendidikan karakter terhadap siswa yaitu faktor sikap dari siswa, faktor keluarga, dan faktor lingkungan pergaulan.
\end{abstract}

\begin{abstract}
The purpose of this research is to know the effort and constraints civics and Citizenship teachers in implementing character education in students of SMA Negeri 2 Donggo community. This research is qualitative research with a descriptive approach. The subject of the information is PPKn teachers, principals, and students. The technique of sampling using purposive sampling. Research data obtained through the method of observation, interviews, and documentation. The type of data in the form of qualitative data. Data sources, namely primary and secondary data sources. Analysis of the data used is the reduction of the data, the presentation of data, and verify. Based on the results of the study, it was concluded that the efforts of the civics and Citizenship teachers in implementing character education on students have already done well. This appears from the integrating character education by teachers in every time the meeting via the subjects and outside subjects or real participation. While constraints civics and Citizenship teachers in implementing character education towards students, i.e., students of attitude factors, family factors, and environmental factors in socialization.
\end{abstract}

\section{A. LATAR BELAKANG}

Pendidikan merupakan salah satu upaya untuk membangun sumber daya manusia, karena pendidikan menyangkut seluruh aspek kehidupan manusia. Keberhasilan sebuah pendidikan tidak hanya diukur melalui materi dan kecanggihan teknologi yang digunakan, akan tetapi juga di tentukan oleh keluhuran karakter dan budi pekerti yang luhur. Hal ini dikarenakan dalam dunia pendidikan tidak hanya semata-mata ditentukan oleh kecerdasan intelektual saja akan tetapi diperlukan juga kecerdasan emosi dan sosial.

Pendidikan Nasional berfungsi mengembangkan kemampuan dan membentuk watak serta peradaban bangsa yang bermartabat dalam rangka mencerdaskan kehidupan bangsa, bertujuan untuk berkembangnya potensi peserta didik agar menjadi manusia yang beriman dan bertakwa kepada Tuhan Yang Maha Esa, berakhlak mulia, sehat, berilmu, cakap, kreatif, mandiri, dan manjadi warga negara yang demokrasi serta bertanggung jawab"[1]. Penyelenggaraan pendidikan sebagaimana yang diamanatkan dalam Undang-Undang tersebut diharapkan dapat mewujudkan proses berkembangnya kualitas pribadi peserta didik sebagai generasi penerus bangsa di masa depan.

Untuk tercapainya pendidikan tersebut maka diperlukan seseorang profesional yaitu guru. Guru merupakan salah satu komponen manusiawi dalam proses pembelajaran yang ikut berperan dalam usaha pembangunan sumber daya manusia yang potensial sebagai investasi dalam bidang pembangunan melalui 
olah pikir. Keberadaan guru demikian bagi suatu bangsa sangatlah penting, terlebih-lebih bagi keberlangsungan hidup bangsa di tengah-tengah lintasan perjalanan jaman dengan teknologi yang kian canggih dan segala perubahan serta pergeseran nilai yang cenderung memberi nuansa negatif dalam kehidupan siswa. Maka, peran guru sangat diperlukan dalam tercapainya pendidikan yang diamanatkan dalam Undang-Undang Dasar 1945.

Istilah pendidikan karakter di Indonesia ditegaskan mulai diperkenalkan sekitar tahun 2000-an. Hal ini secara implisit ditegaskan dalam Rencana Pembangunan Jangka Panjang Nasional (RPJN) 2005-2025, yang menempatkan pendidikan karakter sebagai landasan mewujudkan visi pembangunan Nasional, yaitu "mewujudkan masyarakat yang berakhlak mulia, bermoral, beretika, berbudaya, dan beradap berdasarkan Pancasila dan Undang-undang Dasar Negara Republik Indonesia Tahun 1945 [2].

Berdasarkan Permendikbud Republik Indonesia No. 20 tahun 2018 tentang Penguatan Pendidikan Karakter pada satuan Pendidikan Formal sesuai pasal 1 memutuskan bahwa, penguatan pendidikan karakter yang selanjutnya disingkat PPK adalah gerakan pendidikan di bawah tanggung jawab satuan pendidikan untuk memperkuat karakter peserta didik melalui harmonisasi olah hati, olah rasa, olah pikir, dan olah raga dengan pelibatan dan kerja sama antara satuan pendidikan, keluarga, dan masyarakat sebagai bagian dari Gerakan Nasional Revolusi Mental (GNRM). Dan Satuan Pendidikan Formal, adalah kelompok layanan pendidikan yang menyelenggarakan pendidikan formal, terstruktur dan berjenjang, terdiri atas taman kanakkanak (TK), satuan pendidikan jenjang pendidikan dasar, dan satuan pendidikan jenjang pendidikan menengah yang diselenggarakan oleh pemerintah pusat, pemerintah daerah, dan masyarakat. Sedangkan Satuan Pendidikan Nonformal adalah kelompok layanan pendidikan yang menyelenggara-kan pendidikan di luar pendidikan formal yang dapat dilaksanakan secara terstruktur dan berjenjang.

Sehingga karakter peserta didik sangat berpengaruh terhadap kemajuan anak bangsa.

Terkait dengan SMA Negeri 2 Donggo, sebagai satu sekolah yang sedang menerapkan pemahaman tentang pendidikan karakter, yang sebagian besar siswanya berasal dari keluarga menengah ke bawah. Lingkungan sekolah SMA Negeri 2 Donggo terbentuk sangat beragam mulai dari sifat siswa, tingkat kematangan siswa, tingkat pemahaman sampai pada perilaku alami yang dialami pada masa perkembangannya dalam hal ini adalah kenakalan remaja seperti merokok, membolos saat jam pelajaran, berkata tidak sopan dengan teman, melakukan perkelahian dan datang sekolah terlambat.
Keadaan tersebut menuntut adanya usaha dari sekolah untuk membentuk perilaku atau karakter yang positif. Usaha tersebut dapat ditempuh dengan berbagai strategi dan metode. Pihak-pihak yang dapat melibatkan dalam usaha pembentukan karakter-karakter tersebut meliputi manajemen dan sumber daya manusia.

Melihat dari segi manajemen, misalnya terwujud dalam sebuah kegiatan yang dapat diatur secara baik yang bisa dijalankan melalui berbagai program kegiatan. kegiatan tersebut harus berjalan dengan baik dalam membangun dan memastikan hubungan kerjasama yang produktif dan harmonis, mulai dari perencanaan, pelaksanaan, dan pengawasan, misalnya dalam kegiatan belajar mengajar, kegiataan keagamaan, bakti sosial, siswa dituntut untuk bisa melakukan secara tertib dan disiplin. Peran guru sangat diperlukan untuk pengawasan dalam kegiatan untuk program membantu pendidikan karakter siswa tersebut.

Sehingga kiranya perlu diadakan penelitian yang lebih mendalam oleh penulis untuk dapat menemukan informasi baru dalam membentuk karakter peserta didik yang nantinya dapat diimplementasi dalam kehidupan sehari-hari.

Adapun upaya guru untuk mengimplementasikan pendidikan karakter terhadap anak dapat digunakan beberapa indicator pendidikan karakter yaitu nilai karakter religious, jujur, toleransi, disiplin, kerja keras, kreatif, mandiri, demokratis, rasa ingin tahu, semangat kebangsaan, cinta tanah air, menghargai prestasi, bersahabat, cinta damai, gemar membaca, peduli lingkungan, peduli social dan tanggung jawab[3].

Sementara lainhya menjelaskan bahwa karakter yang harus ditanamkan kepada peserta didik di antaranya adalah; cinta kepada Allah dan alam semesta beserta isinya, tanggungjawab, disiplin dan mandiri, jujur, hormat dan santun, kasih sayang, peduli, dan kerja sama, percaya diri, kreatif, kerja keras dan pantang menyerah, keadilan dan kepemimpinan, baik dan rendah hati, dan toleransi, cinta damai dan persatuan. Sedangkan akhlak mulia adalah keseluruhan kebiasaan manusia yang berasal dalam diri yang di dorong keinginan secara sadar dan dicerminkan dalam perbuatan yang baik. Dengan demikian apabila karakterkarakter yang luhur tertanam dalam diri peserta didik maka akhlak mulia secara otomatis akan tercermin dalam perilaku peserta didik dalam kehidupan keseharian[4].

Guru PKn dalam membentuk karakter peserta didik memiliki peranan yang sangat penting. Karena PKn merupaka pelajaran yang bertujuan untuk membentuk warganegara yang baik dalam kehidupan sehari-hari atau dalam kehidupan berbangsa dan bernegara. Dengan demikian, peserta didik diharapkan memiliki kepribadian yang sesuai dengan nilai-nilai pancasila 
sehingga terciptalah generasi bangsa yang cerdas dan bermoral[5].

Berbagai masalah yang diuraikan di atas, sangat penting untuk membuktikan kembali seyogyanya upaya dalam meningkatkan karakter anak melalui pendidikan pancasila dan kewarganegaraan. Tujuan yang ingin dicapai dalam penelitian ini adalahuUntuk mengetahui upaya guru pendidikan Pancasila dan Kewarganegaraan dalam mengimplementasi pendidikan karakter pada siswa SMA Negeri 2 Donggo, dan untuk mengetahui kendala-kendala apa saja upaya guru pendidikan Pancasila dan Kewarganegaraan dalam mengimplementasi pendidikan karakter pada siswa SMA Negeri 2 Donggo.

\section{B. METODE PENELITIAN}

\section{Metode yang Digunakan}

Metode yang digunakan dalam penelitian ini adalah metode kualitatif dengan pendekatan deskriptif. Metode penelitian kualitatif adalah metode penelitian yang digunakan untuk meneliti pada kondisi obyek yang alamiah, (sebagai lawannya adalah eksprimen), dimana peneliti adalah sebagai instrumen kunci, tehnik pengumpulan data dilakukan secara triangulasi (gabungan), analisis data bersifat induktif, dan hasil penelitian kualitatif lebih menekankan makna dari pada generalisas[6]. Sedangkan pendekatan deskriptif digunakan untuk berupaya memecahkan atau menjawab permasalahan yang sedang dihadapi pada situasi sekarang. Dilakukan dengan menempuh langkahlangkah pengumpulan, klasifikasi, dan analisis atau pengolahan data, membuat kesimpulan dan laporan dengan tujuan utama untuk membuat gambaran tentang sesuatu keadaan secara objektif dalam suatu deskriptif situasi. Itulah sebabnya disebut dengan pendekatan deskriptif “[7].

Penggunaan metode kualitatif deskriptif ini dikarenakan dalam penelitian data yang dihasilkan berupa data deskriptif yang diperoleh dari tulisan, katakata dan dokumen yang berasal dari sumber atau informasi yang diteliti dan dapat dipercaya serta untuk mendapatkan data yang mendalam dan menemukan apa yang tersembunyi nilai-nilai dibalik yang nampak.

\section{Subjek Penelitian}

Subyek penelitian merupakan sesuatu yang kedudukannya sangat sentral karena pada subyek penelitian itulah data tentang variabel yang diteliti berada dan diamati oleh peneliti [8]. Sementara tehnik sampling yang sering digunakan dalam penelitian kualitatif adalah tehnik purposive sampling dan snowball sampling. Purposive sampling adalah tehnik pengumpulan sampel sumber data dengan pertimbangan tertentu. Pertimbangan tertentu ini misalnya orang tersebut dianggap paling tau tentang apa yang kita harapkan, atau mungkin sebagai penguasa sehingga akan memudahkan penelitian menjelajahi obyek atau situasi sosial yang diteliti. Snowball sampling adalah teknik pengabilan sampel sumber data, yang pada awalnya jumlahnya sedikit, lama-lama menjadi besar. [9]

Dengan demikian teknik pengambilan sampel dengan tehnik sampel purposive sampling yang digunakan, karena informasi ini dianggap lebih mengetahui dan lebih faham terhadap masalah yang diteliti dan dapat memberikan data yang lebih lengkap dan tidak menggunakan istilah populasi. Jadi yang menjadi subyek penelitian dalam penelitian ini adalah guru PPKn, Kepala Sekolah, dan Siswa.

\section{Teknik Pengumpulan Data}

Untuk mendapatkan data yang lebih jelas, maka tehnik pengumpulan data yang digunakan dalam penelitian ini adalah:

\section{a. Metode Observasi}

Metode observasi biasa diartikan sebagai "pengamatan dan pencatatan secara sistematik terhadap gejala yang nampak pada obyek penelitian”. Gejalagejala yang dimaksud adalah hal-hal yang berhubungan dengan upaya guru PPKn dalam mengimplementasikan pendidikan karakter pada siswa obyek studi. Observasi adalah dasar semua ilmu pengetahuan. Para ilmuan hanya dapat bekerja berdasarkan data, yaitu fakta mengenai dunia kenyataan yang diperoleh melalui observasi [9].

\section{b. Metode Wawancara}

Metode wawacara adalah metode pengambilan data dengan cara menanyakan sesuatu kepada seorang menjadi informan atau responden. Cara adalah dengan bercakap-cakap secara tatap muka[10]. Wawancara merupakan pertemuan dua orang yang bertukar informasi dan ide melalui tanya jawab, sehinggah dapat dikontruksikan makna dalam suatu topik tertentu [9].

Wawancara atau interviu terdiri dari atas tiga jenis, yaitu sebagi berikut: [10]

1. Wawancara terstruktur, yaitu wawancara yang pertanyaan telah disiapkan, seperti menggunkana pedoman wawancara, berate telah mengetahui data dan menentukan fokus serta perumusan masalah.

2. Wawancara semi terstruktur, yaitu wawancara yang sudah cukup mendalam karena ada penggabungan antara wawancara yang berpedoman pada pertanyaan-pertanyaan yang telah dipersiapkan dan pertanyaan yang lebih luas dan mendalam dengan mengabaikan pedoman yang sudah ada.

3. Wawancara tidak terstruktur adalah wawancara yang lebih bebas, lebih mendalam, dan menjadikan pedoman wawancara sebagai pedoman umum dan garis-garis besarnya saja.

Adapun wawancara yang digunakan dalam penelitian ini adalah wawancara tidak terstruktur. Maksud digunakan wawancara tidak tertruktur dalam penelitian ini adalah untuk mendapatkan informasi awal tentang berbagai isu atau permasalahan yang ada pada 
obyek penelitian. Sehingga peneliti dapat menentukan secara pasti permasalahan atau variabel yang akan diteliti. Teknik ini bertujuan untuk memperoleh informasi dan keterangan dari informasi yang berkaitan dengan masalah upaya guru pendidikan pancasila dan kewarganegaraan dalam mengimplentasikan pandidikan karakter pada siswa SMA Negeri 2 Donggo.

\section{c. Metode Dokumentasi}

Metode dukumentasi adalah tehnik pengumpulan data dan informasi melalui pencarian dan penemuan bukti-bukti, metode dokumentar ini merupakan metode pengumpulan data yange berasal dari sumber nonmanusia [10]. Sumber nomamanusia ini sering di abaikan dalam penelitian kualitatf, pada sumber ini kebanyakan sudah tersedia dan siap pakai. Dokumen berguna dapat memberikan latar belakang yang lebih luas mengenai pokok penelitian. Salah satu bahan dokumentar adalah foto atau karya-karya dari seseorang. Foto bermanfaat sebagai sumber informasi karena mampu membekukan dan manggambarkan perisrtiwa yang terjadi.

\section{Teknik Analisi Data}

Analisis data adalah proses mencari dan menyusun secara sistematis data yang diperoleh dari hasil wawancara, catatan lapangan, dan bahan-bahan lain, sehingga dapat mudah difahami, dan temuannya dapat diformasikan kepada orang lain Bogdan dalam[9].

Adapun langkah yang dilakukan dalam mengalisis data [11] meliputi, Reduksi data adalah proses pemilihan, pemusatan perhatian pada penyerdehanaan, pengabstraksian dan transpormasi data kasar dari catatan tertulis selama di lapangan. Untuk mereduksi data peneliti membuat ringkasan kontak, mengembangkan kategori, pengkodean dan membuat catatan refleks yang bermaksud menajamkan, menggolongkan, mengarahkan yang tidak berlaku. Kemudian mengorganisasikan sedemikian rupa sehingga kesimpulan mendapatkan hasil yang tepat, ini dilakukan terus-menerus selama penelitian berlangsung. Penyajian data adalah merupakan sekumpulan informasi tersusun yang memberikan kemungkinan adanya penarikan kesimpulan dan penarikan tindakan. Data teks naratif penelitian dijadikan dalam bentuk metrik, diagram, jaringan, dan tabel yang dirancang peneliti untuk menggabungkan informasi yang diinformasikan dalam bentuk sederhana dan terpadu, sehingga dapat melihat apa yang sedang terjadi. Kesimpulan atau verivikasi adalah upaya yang diperoleh selama pengumpulan data berlangsung. Penulis melakukan kesimpulan sejak awal pengumpulan data. Kesimpulan yang kurang jelas. Meningkatkan semakin rinci dan menyusun laporan final selesai. Untuk kesimpulan final peneliti terus mengadakan pengujian (verivikasi) selama peneliti berlangsung dengan berbagai cara antara lain meninjau ulang catatan di lapangan.

\section{HASIL DAN PEMBAHASAN}

1. Upaya Guru Pendidikan Pancasila dan Kewarganegaraan dalam Mengimplementasi Pendidikan Karakter pada Siswa

Keberhasilan sebuah pendidikan tidak hanya diukur melalui materi dan kecanggihan teknologi yang digunakan, akan tetapi keleluhur karakter siswa sangat perlu dibentuk. Sebagaimana sesuai dengan misi sekolah yang tertulis dalam poin pertama, keempat dan kelima yang mengedepankan dalam bertutur dan bertindak untuk mengenali potensi dirinya lebih optimal dan meningkatkan kegiatan-kegiatan ekstrakurikuler untuk pembentukan karakter siswa.

Upaya yang dilakukan oleh guru pendidikan pancasila dan kewarganegaraan dan kepala sekolah adalah mulai dari kegiatan ko-kurikuler, ekstrakurikuler, dan metode untuk membantu menanamkan nilai-nilai pendidikan karakter pada siswa. Hal tersebut sebagaimana yang di ungkapan dari bapak Ahmad guru PPKn kelas XII.

Kegiatan ko-kurikuler yaitu di dalam kelas setiap kali pertemuan melalui KBM. Sedangakan kegiatan ekstrakurikuker kami lakukan sekali dalam setahun, karena saya juga termasuk pembina kepramukan. Kegiatan ekstrakurikuker itu sangat membantu menumbuhkan siswa kearah yang lebih baik, karena cara menanamkan nilai-nilai karakter yang baik perlu di bentuk oleh pengelolah.

Upaya tersebut dapat dilihat berdasakan observasi peneliti dari sebelum kegiatan belajar mengajar berlangsung (KBM), seorang guru harus sadar akan posisinya sebagai pendidik agar bisa menjadi teladan untuk siswanya karena orang tua siswa sudah memberikan tanggung jawab pada pihak sekolah dan guru dalam memberikan ilmu pengetahuan serta mendidik siswa agar mempunyai ahlak yang mulia, karena sekolah bukan hanya tempat formalitas dalam dunia pendidikan yang hanya sekedar memberikan materi dan siswa bukan cuman mendengarnya, tetapi guru di sekolah bisa membentuk karakter siswa yang baik, dalam kondisi sosial setiap tingkah laku guru akan dapat mempengaruhi moralitas siswa, untuk itu profesionalitas guru dalam mendidik, membimbing dan mengajar sangat dibutuhkan dalam sekolah sehingga tujuan pendidikan yang mengedepankan dalam membentuk karakter siswa dapat dilakukan dengan secara efektif dalam sekolah. Guru juga harus bisa profesional dalam menjalankan posisinya sebagai pendidik sebab guru merupakan salah satu profesi yang diandalkan untuk mencetak dan membentuk karakter generasi bangsa.

Wawancara dengan Ahmad selaku guru PPKn pengajar kelas XII SMAN 2 Donggo.

"Upaya yang saya lakukan dalam membentuk karakter siswa yaitu dengan memberikan contoh yang baik kepada peserta didik, serta 
melakukan hal-hal yang positif baik di lingkungan sekolah maupun di lingkungan masyarakat, terutama nilai agama karena didalam agama apapun selalu mengajak ke hal yang baik, selain itu juga nilai-nilai atau norma-norma yang berlaku di negara kita, dan jika ada siswa yang melanggar atau melakukan kesalahan guru akan memberikan arahan serta membinanya supaya dia tidak melakukan lagi kesalahan-kesalahan yang sama, baru setalah itu kami melakukan peneguran. Metode yang saya gunaka terutama dalam kelas yaitu metode cerama, diskusi, dan metode kooperatif" (hasil wawancara 6 Agustus 2017).

Hasil serupa juga diungkapkan oleh bapak Sumarno Wirawan selaku guru PPKn pengajar kelas XI SMAN 2 Donggo:

"Sebelum kegiatan belajar mengajar berlangsung (KBM), saya mengupayakan memberi arahan dan menasehati dulu anakanak dalam kelas untuk menjadi orang baik dan teladan bagi orang lain seperti tidak bole bolos di jam sekolah, jika tidak masuk sekolah harus kirim surat untuk menjadi keterangannya, dan saya salalu mengupayakan anak-anak agar tidak melakukan perkelahian atau kekerasan antar visik, karena perkelahian mereka bukan hanya kelahi biasa selama ini tapi sering mengalami sampai keluar darah, perkelahian anak-anak selalu membawa nama antar kampung, dan perkelahian anak-anak di sekolah sampai turun tangan langsung polisi menangalinya dan kami sebagai guru sudah tidak bisa mengatasinya mereka, maka dari itu saya sebagai guru PPKn mengusahakan untuk membentuk karakter yang baik terhadap anakanak terutama melalui kegiatan keagamaan masing-masing dan mentaati aturan yang ada baik di sekolah maupun di masyarakat supaya tidak terjadi lagi kekerasan yang mengerikan, karena hal demikian masih ada terjadi sekarang, dan saya dengan seluruh guru-guru disini tetap mendidik anak-anak agar menjadi apa yang diharapkan kedepannya anak-anak menjadi orang yang baik" (hasil wawancara 15 Agustus 2018).

Ibu Ros selaku guru PPKn pengajar kelas X SMAN 2

Donggo mengungkapkan.

'Saya sebagai guru mengupayakan anak-anak menjadi orang yang baik, baik sebelum belajar maupun pada saat belajar berlangung dengan memberikan contoh mengkaitkan materi dengan kehidupan sehari-hari, yaitu dengan mengajarkan untuk memegang teguh prinsip nilai-nilai religius, moral dan HAM. Mengajak anak-anak berdiskusi mengenai prinsip menghargai orang lain dan kewajiban sebagai anggota sistem sosial, dan memberikan pengalama nyata partisipasi dan komunitas misalnya melalui organisasi kepramukaan (ekstrakurikuler) dan sebagainya dan metode yang sering saya gunakan adalah metode kooperatif, karena metode kooperatif merupakan cara yang luas untuk mendukung karakter siswa yang baik melalui kerjasama dalam proses belajar di dalam kelas" (Wawancara, 20 Agustus 2018).

Bahwa guru bukan hanya mentrasfer ilmu pengetahuan dan mengejar materi tetapi guru harus bisa mendidik anak-anak menjadi orang yang bermoral yaitu dengan mengimplementasikan pendidikan karakter. Karena yang diinginkan dalam kurikulum 2013 sesuai dengan KI 1 yang memuat pembelajaran spiritual dan KI 2 yang memuat tentang (kejujuran, tanggung jawab, kerjasama dengan berinteraksi secara aktif dalam lingkungan sosial sehingga akan membentuk nilai-nilai ahlak mulia yang bisa membentuk karakter siswa yang baik dan bermoral.

Selanjutnya wawancara dengan bapak Nasaruddin, selaku kepala sekolah SMAN 2 Donggo mengungkapkan.

"Upaya yang kami lakukan dengan seluruh guru di sini terutama dengan guru PPKn dalam membina atau membentuk karakter siswa kami melaksanakan kegiatan salah satunya yang pertama upacara bendera, itu merupakan langkah awal untuk membentuk disiplin, karena sumber watak atau kepribadian manusia tergantung dari kepribadiannya. Kepribadian akan terbentuk dari pengelolah oleh seseorang satuan pendidikan nasional untuk membentuk watak anak-anak salah satunya guru. Selain itu kami melakukan kegiatan ekstrakurikuler yaitu kepramukaan sebagai langkah nyata didalam membentuk watak ana-anak, disamping kegiatan ektranya disini juga anak-anak wajib lapor, jika anak-anak mendapat masalah sudah diberi pengarahan dan dibuat surat pernyataan, surat pernyataan itu wajib melapor, jadi jika siswa berturut-turut 2 kali pertemuan tidak hadir maka akan di panggil, dan siswa-siswa yang sering melakukan perkelahian akan mendapat surat pernyataan untuk memanggil orang tuanya maka dari itu kami akan melakukan kerjasama dalam mengatasi anak tersebut" (hasil wawancara, 20 Agustus 2018).

Bahwa dalam mengimplementasikan pendidikan karakter pada siswa SMAN 2 Donggo, guru dapat melakukan berbagai kegiatan untuk mendukung kedisiplinan dalam membentuk karakter siswa yaitu kegiatan ektrakurikuler, karena tugas guru bukan hanya memberikan ilmu pengetahuan saja akan tetapi harus mendidik siswa-siswa kearah yang baik. Suasana sosial di sekolah dan bagaimana guru-guru bertingkah laku akan memberikan pengaruh secara tidak langsung kepada pembelajaran pendidikan karakter. Guru juga harus menerima hakikat bahwa nilai-nilai ahlak atau moral sudah tertanam dalam diri siswa. Dan guru harus bersedia untuk mengajar dengan pengetahuan dan pembelajaran dalam menerapkan pendidikan karakter. Guru dikehendakai untuk mengimplementasikan pendidikan karakter pada siswa dan membimbing mereka semasih ada di lingkungan sekolah. Pendidikan di sekolah digunakan untuk meningkatkan pengetahuan pendidikan karakter pada siswa ke arah untuk mencapai 
kesuksesan sesuai dengan kurikulum untuk melahirkan individu yang bermoral dan berahlak tinggi.

Berdasarkan hasil wawancara di atas serta hasil pengamatan/observasi di lapangan dapat disimpulkan bahwa upaya guru PPKn dan kepalah sekolah dalam membentuk karakter siswa sudah terpapar dalam berbagai kegiatan yang dilakukan oleh guru terhadap siswa;

1. Imtaq merupakan kegiatan yang dilakukan oleh guru setiap hari jumat dengan seluruh siswa, kecuali siswa non muslim itupun ada bi bimbingan khusus, dan sebelum mulai proses kegiatan belajar mengajar (KBM) ataupun sesudah proses belajar diakhiri pula dengan doa, serta membiasakan siswa memberikan salam terhadap guru, dan guru memberika pengarahan yeng berkaitan dengan kehidup antar umat beragama untuk saling menghargai baik dari segi perbedaan pendapat maupun dalam bentuk kerja sama dengan orang lain . Hal demikian merupakan bentuk tindakkan yang dilakukan oleh guru untuk menanamkan nilainilai religius, tolerans, bersahabat/komunikatif, dan cinta damai dalam membentuk karakter siswa.

2. Peraturan sekolah, jam 07:15 Wita siswa harus masuk di dalam kelas tampa terkecuali, dan setiap hari senin dilaksakan kegiatan upacara bendera siswanya harus menyanyikan lagu Indonesia raya dengan baik pada saat pengibaran sang merah putih serta memakai seragam terutama topi, daci, dan baju harus stael dalam, dan sekali setahun guruguru mengadakan kegiatan pramuka dengan tujuan untuk membentuk watak siswa, karena dalam pramuka banyak hal yang dipelajari oleh siswa. Kegiatan-kegiatan tersebut adalah cara guru tehadap siswa untuk menanamkan nilai-nilai kedisiplina, kejujuran, dan cinta tanah air/Nasiionalisme.

3. Guru memberikan tugas kepada siswa baik secara individu maupun secara kelompok untuk mengerjakan dengan baik, dan mengerluarkan ideidenya yang baru serta percaya pada apa yang dikejakan masing-masing individu maupun secara kelompok, di dalam kelas juga guru memberikan kesempatan kepada siswa untuk berdiskusi dan saling melemparkan pertanyaan kepada kelompok lain tentang hal apa yang belum di mengerti. Berbagai cara yang dilakukan oleh guru di atas adalah untuk membentukkan bentuk kerja keras, kreatif, mandiri dan rasa ingin tahu, itu semua secara tidak langsung dilakukan oleh guru untuk membentuk karakter siswa.

4. Memilih ketua dan wakil ketua kelas serta bendahara kelas yang dilakukan oleh guru melalui cara pemilihan. Kegiatan tersebut merupakan langkah untuk membiasakan siswa dalam menanamkan nilai demokrasi, karena didalam sistem demokrasi akan mempelajari apa yang menjadi hak memilih dan dipilih.

5. Memperingati hari kemerdekaan 17 agustus guruguru mengadakan kegiatan gerak jalan terhadap siswa dalam memperingati hari kemerdekaan Indonesia sebagai wujud rasa semangat kebangsaan.

6. Pada saat tidak ada guru mata pelajaran, siswa disuruh masuk ke perpustakaan untuk mengambil buku, dan menyuruh siswa untuk belajar sendiri, kegiatan demikian bertujuan untuk membentuk karakter siswa melalui gemar membaca.

7. Setiap pagi siswa membersihkan kelas masingmasing bersasarkan jadwal piket, dan selain dari membersihkan kelas, seluruh siswa juga disuruh pungat sampah di keliling arena sekolah. Bentuk kegiatan di atas merupkan cara untuk membentuk karakter siswa dalam menanamkan nilai-nila kepedulian terhadap lingkungan yang ada di sekitar.

8. Baksos, guru melakukan partisipasi nyata dan komunitas bersama siswa turun langsung di jalan raya untuk meminta bantuan dan semua siswa juga memberikan bantuan sebagai kewajiban dalam membantu sesama yang kenah musibah yang membutuhkan bantuan. Kegiata ini akan menumbuhkan rasa kepedulian sosial dan tanggung jawab karena secara tidak langsung juga akan membentuk karakter siswa.

\section{Kendala-Kendala Upaya Guru Pendidikan Pancasila dan Kewarganegaraan dalam Mengimplementasi Pendidikan Karakter pada Siswa SMAN 2 Donggo.}

Fenomena kerusakan moral/akhlak yang menimpa remaja Indonesia secara khusus dan masyarakat Indonesia secara umum telah mendorong Pemerintah Indonesia untuk menerapkan Kebijakan Nasional Pembangunan Karakter Bangsa (KN-PKB). Salah satunya upaya untuk mewujudkan kebijakan tersebut adalah dengan menekankan pentingnya pendidikan karakter untuk diimplementasikan dalam setiap institut pendidikan.

Menurut bapak Nas selaku kepala sekolah, faktor penghambat atau kendala dalam mengimplementasikan pendidikan karakter pada siswa;

"Faktor penghambat atau kendala dalam menerapkan pendidikan karakter sehingga tidak bisa berjalan seratus persen adalah faktor lingkungan, dan itu juga tidak berarti seberapa berat karena itu tugas dari para guru karna itu hal biasa, sebab tampa ada kendala atau penghambat maka kita tidak akan ada perubahan, kendala tersebut tidak ada yang disignifikasikan. Dan untuk mengantisipasi menghindari siswa dari hal-hal negatif yaitu diberikan pengarahan baik secara individu 
maupun secara kelompok" (wawancara 20 Agustus 2018).

Bahwa faktor penghambat atau kendala bukanlah suatu masalah semata yang membuat guru gagal dalam melaksanakan sesuatu terutama dalam mengimplementasikan pendidikan karakter pada siswa, tetapi tugas guru adalah mencari jalan keluar untuk memecahkan masalah yang dihadapi.

Informasi dari Ah, kendala-kendala upaya guru pendidikan pancasila dan kewarga-negaraan dalam mengimplementasikan pendidikan karakter pada siswa.

"Faktor penghambat atau kendala dalam membentuk tingkah laku siswa yang pertama faktor lingkungan. Anak yang sudah terbiasa hidup di lingkungan masyarakat yang penuh dangan kekacauan apalagi dengan pergaulan anak-anak sekarang bukan lagi seperti dulu yang mudah dipantau pergaulannya tapi sekarang anak-anak sudah banyak yang bisa memake barang-barang terlarang, sehingga susah diatasi oleh guru-guru. Yang kedua faktor kelurga, anak sedikit-sedikit di bentak langsung kasih tau keluarganya dan kelurganya datang mengancam guru. Yang ketiga diberlakukan UU perlindungan anak, sehingga sudah banyak guru yang tidak mau mengambil resiko, karena sudah banyak guru yang di penjara gara-gara membentuk atau mendidik anak-anak yang tidak sesuai dengan keinginan masyarakat. Dan cara saya mengatasinya yaitu dengan cara mengajarkan atau memberikan contoh-contoh yang baik serta membimbingnya untuk tidak melakukan hal-hal negatif. Yang kedua melakukan pendekatan individu guna mengetahui sifat dan perilaku dari peserta didik tersebut, karena antara peserta didik yang satu dengan yang satu berbeda karakternya, sehingga penangannyapun berbeda caranya" (Wawancara 6 Agustus 2018)

Bahwa faktor penghambat dalam mengimplementasikan pendidikan karakter pada siswa, yaitu faktor lingkungan pergaulannya dan keluarga, karena dimana anak-anak dijaman sekarang semakin tidak terpantau dengan baik dengan siapa mereka bergaul di lingkungan. Apabila nilai moral atau karakter anak itu baik tapi teman-teman dalam pergaulannya tidak menanamkan nilai moral dan karakter yang baik maka anak tersebut juga akan ikut terpengaruh ke hal yang tidak baik juga.

Informasi dari SW faktor-faktor penghambat upaya guru pendidikan pancasila dan kewarganegaraan dalam mengimplementasi-kan pendidikan karakter pada siswa. Karakter anak pada masa peralihan banyak hal yang ingin mereka coba, dilihat dari kenyataannya perkelahian anak setiap minggu tetap ada di lingkungan sekolah dan sering bolos, karena pada masa peralihan itu anak-anak mudah terpanci emosinya oleh hal-hal yang sepele, dan ingin dipuji bahwa dirinya kuat. Hal tersebut sesuai dengan ungkapan bapak S.W guru PPKn.

"Saya selaku guru PPKn sudah mengupayakan semaksimal mungkin dalam mendidik dan membentuk karakter siswa, tetepi upaya yang saya lakukan mengalami penghambat atau kendala seperti dalam proses pembelajaran berlangsung masih ada yang bolos dan keluar masuk dalam kelas alasan pergi ke kamar mandi, karena tidak semua siswa bisa mentaati aturan, itu semua disebabkan oleh beberapa faktor yang sudah terbiasa mereka lakuka, yang pertama ada dari faktor lingkungan keluarga, faktor sikap dari diri siswa dan yang paling besar adalah dari lingkungan masyarakat mereka bergaul". (wawancara 15 Agustus 2018).

Bahwa kendala /faktor penghambat dalam upaya menerapkan pendidikan karakter adalah faktor lingkungan dimana tempat anak-anak bergaul, karena pengaruh dalam pergaulannya itu sangat besar.

Demikian juga hasil ungkapan dari Ros menyatakan kendala/faktor yang menghambat dalam mengimpementasikan pendidikan karakter adalah sebagai berikut;

"Kendala/Faktor yang menghambat yaitu faktor lingkungan, anak yang semula berkarakter jujur akan berubah jadi malas, sering bolos dan sering melakukan perkelahian karena berada di lingkungan yang kurang kondusif. Namun anak yang berada dalam lingkungan yang baik akan menumbuh subur nilai-nilai kejujuran yang sudah dimiliki anak tersebut. Sistem dan proses yang berlangsung di lembaga sekolah hendaknya berorentasi pada nilai kejujuran peserta didik, dan hasil yang diharapkan perlu di raih dengan kejujuran. Saya sebagai guru tetap mengupayakan walapun terasa agak sedikit susah dari sebagian anak-anak, karena itu merupakan tugas saya sebagai tenaga pendidik untuk memecahkan sebuah masalah terhadap anak peserta didik di sekolah" (wawancara 20 Agustus 2018).

Jadi kendala/penghambat dalam upaya guru dalam mengimplementasi pendidikan adalah faktor lingkungan, keluarga, dan faktor sikap siswa sendiri.

\section{TEMUAN DAN DISKUSI}

Upaya adalah usaha akal atau akhtiar untuk mencapai suatu maksud, memecahkan persoalaan, mencari jalan keluar dalam menghadapi masalah maka upaya adalah suatu usaha yang dilakukan dengan maksud tertentu agar semua permasalahan yang ada dapat terselesaikan dengan baik dan dapat mencari tujuan yang diharapkan. Dalam hal ini upaya guru dalam membentuk karakter siswa adalah peranan sesorang guru dengan suatu kegiatan atau metode secara terusmenerus yang dilakukan oleh pendidik terhadap peserta didik sebagai upaya pembentukan karakter siswa sejak usia sekolah MI/sekolah menengah, sehingga peranan guru tidak lain terintenalisasi nili-nilai karakter terhadap diri peserta didik sehingga memunculkan sikap dan perilaku yang berkarakter mulia.

Berdasarkan hasil observasi dan wawancara yang dilakukan peneliti mengenai upaya guru dalam 
mengimplementasikan pendidikan karakter pada siswa, maka ditemukan karakter sebagai berikut:
a) Religius
b) Kejujuran
c) Toleransi
d) Disiplin
e) Kerja keras
f) Kreatif
g) Mandiri
h) Demokrasi
i) Rasa ingin tahu
j) Semangat kebangsaan atau nasinalisme
k) Cinta tanah air
l) Menghargai prestasi
m) Bersahabat/komunikatif
n) Cinta damai
o) Gemar membaca
p) Peduli lingkungan
q) Kepedulian sosial
r) Tanggung jawab

Kendala-kendala upaya guru pendidikan pancasila dan kewarganegaraan dalam mengimplementasikan pendidikan kara-kter pada siswa dapa diuraikan sebagai berikut:

\section{Faktor Sikap Siswa}

Berdasarkan hasil observasi dan wawancara yang terjadi di lapangan bahwa, sikap siswa di sekolah sudah baik dalam etikanya, namun masih banyak siswa-siswa yang susah dikendalikan oleh guru terutama yang berkaitan dengan perkelahian. Perkelahian ini sering terjadi mulai dari angkatan 2016 sampai sekarang masih susah diatasi tetapi sudah mulai berkurang ketimbang tahun yang lalu. Hal ini perlu disadari oleh kita semua, karena apabila hal ini dibiarkan begitu saja maka generasi bangsa akan rusak, sebab akan muncul kriminal-krimial besar.

Sikap siswa berbeda-beda inilah yang menjadi faktornya seperti masalah siswa baik di rumah, sekolah dan di lingkungan. Karakter terhadap tiap-tiap anak ini, guru harus bisa menilai dan melakukan sesuatu untuk membentuk tingkah laku siswa, dan untuk membentuk tingkah siswa bukan segampang kita balik telapak tangan tampa ada kesadaran dari siswa cepat atau lambat, dan jika siswa sadar akan pentingnya nilai moral dalam dirinya, maka siswa akan sadar hukuman atau sanksi apa yang didapat jika melanggar tatatertib sekolah maupun di masyarakat.

Sikap seseorang akan terbentuk karena ada objek tertentu yang memberikan rangsangan pada dirinya. Sikap adalah bagian yang penting dalam berinteraksi dengan orang lain. Sikap berkaitan dengan motif dan mendasari tingkah laku seseorang dapat diramalkan tingkah laku apa yang dapat terjadi dan akan diperbuat jika diketahui sikapnya.

\section{Faktor Keluarga}

Lingkungan keluarga sangat memiliki berperan penting dalam diri siswa. terutama dalam hal mendidik tentang nilai-nilai moral untuk membentuk karakter siswa, karena watak anak yang terbawa sampai ke sekolah merupakan cerminan dari rumah, jika kebiasaan siswa saat di rumah sudah terbentuk bisa mentaati aturan dalam bentuk kedisiplinan, maka siswa di sekolah akan disiplin juga. Orang tua kurang memperhatikan dalam menanamkan nilai-nilai moral untuk membentuk karakter siswa ketika berada di rumah secara tidak langsung akan mempengaruhi sikap siswa ketika berada di lingkungan sekolah dan masyarakat. Hal ini disebabkan karena didalam diri siswa tidak tertanam nilai-nilai moral yang baik, karena ketika siswa berada di luar sekolah itu sudah menjadi tanggung jawab kelurga. Oleh karena itu kelurga atau orang tua siswa harus memperhatikan dan menanamkan nilai moral yang baik di rumah pada anak-anak.

Dalam mengimplementasikan pendidikan karakter untuk membentuk suatu kedisiplinan pada siswa, pihak guru sangat membutuhkan orang tua siswa dalam menangani permasalahan yang dihadapi oleh siswanya. Karena sikap siswa yang kurang sesuai dengan siswa seusianya sudah menjadi salah satu hal yang mengharuskan guru mengadakan kerjasama dengan orang tua siswa. Guru akan merasa sulit menangani siswa-siswa tampa ada adanya bantuan dari pihak yang terkait langsung dengan siswa yaitu orang tua siswa. Keberadaan siswa yang lebih banyak adalah di rumah daripada di sekolah, jadi guru mengharuskan orang tua untuk bisa memahami penyimpangan apa yang sudah terjadi kepada anak. Keterkaitan yang disignifikasi antara pendidikan yang dilakukan orangtua terhadap anak dalam keluarga dengan karakter anak sesungguhnya di masa depan. Artinya bagaimana model penanman nilai yang dilakukan orangtua terhadap anak akan mempengaruhi bagaimana karakter anak yang bersangkutan, dan pada akhinya hal tersebut akan menjadikan indetitas yang bersangkutan pada masa yang akan datang.

\section{Faktor Lingkungan}

Berdasarkan beberapa hasil wawancara dengan guru SMAN 2 Donggo bahwa lingkungan merupakan tempat yang sering menjadi penghambat atau kendala dalam upaya guru membentuk karakter siswa, karena lingkungan adalah tempat cukup berpengaruh dalam pergaulan siswa, siswa akan lebih mudah melakukan penyimpangan karena lingkungan pergaulan yang tidak baik, salah satunya perkelahian yang masih terjadi sekarang itu semuanya disebabkan oleh faktor pergaulan dalam lingkungan yang susah dijangkau. Lingkungan pergaulan akan rentang dalam mempengaruhi siswa, hal ini akan berdampak tidak baik dalam perkembangan siswa kelaknya. 
Perkembangan kepribadian seseorang anak sangat dipengaruhi oleh kondisi lingkungan sosial, budaya setempat, dan tradisi. Sebab lingkungan adalah salah satu faktor penentu tingkah laku seseorang selain keluarga dan sekolah, karena teman pergaulan merupakan faktor yang sangat berpengaruh dalam membentuk karakter siswa yang ada pada dirinya. Apabila anak bergaul dengan teman yang ada nilai moral yang baik, maka anak itu akan kecenderungannya baik, dan apabila anak itu bergaul dengan teman yang tidak mempunyai nilai moral yang baik maka anak tersebut akan cenderung ke hal yang tidak baik pula.

\section{E. SIMPULAN DAN SARAN}

Upaya guru pendidikan Pancasila dan Kewarganegaraan dalam mengimplementasikan pendidikan karakter pada siswa SMAN 2 Donggo, maka peneliti dapat mengambil kesimpulan berdasarkan rumusan masalah yaitu upaya dan kendala guru dalam mengimplementasikan pendidikan karakter pada siswa. Upaya yang dilakukan oleh guru pendidikan Pancasila dan Kewarganegaraan dalam mengimplementasikan pendidikan karakter pada siswa, sudah diintegrasikan diterapkan melalui mata pelajaran. Pengimplementasi pendidikan karakter diterapkan melalui dua proses yaitu melalui kegiatan pembelajaran dan kegiatan di luar pembelajaran atau melalui partisipasi nyata.

Sedangkan kendala guru dalam meng-implementasi pendidikan karakter pada siswa yaitu disebabkan oleh fakor sikap siswa, faktor keluarga, dan faktor lingkungan. Faktor sikap siswa adalah merupakan hal penentu bagi siswa sendiri akan tingkah kesadaran untuk bertindak. Faktor keluarga merupakan hal dasar dalam membentuk karakter atau tingkah laku siswa yang paling utama. Dan faktor lingkungan yaitu faktor yang sangat mempengaruhi seorang anak dalam pergaulannya yang mudah menjerumuskan kearah buruk maupun baik.

Dari hasil penelitian yang diperoleh maka saran yang diberikan peneliti sebagai masukan terhadap seluruh pihak sekolah terutama pada guru pendidikan Pancasila dan Kewarganegaraan dalam mengimplementasi pendidikan karakter pada siswa SMAN 2 Donggo;

1. Diharapkan kepada guru PPKn agar terus berupaya semaksimal mungkin untuk membentuk tingkah laku siswa kearah yang baik.

2. Dihapkan kepada guru PPKn agar tetap melakukan kerjasama dengan kepala sekolah untuk membentuk tingkah laku siswa.

3. Diharapkan kepada guru PPKn agar bekerjasama juga dengan orang tua murid dalam membentuk tingkah lau siswa, karena apabila ada dukungan dari orang tua murid maka cara memecahkan masalah terhadap siswa akan mudah.

4. Diharapkan kepada seluruh pihak sekolah atau guru-guru SMAN 2 Donggo agar bekerjasama dalam memecahkan masalah terkait dalam pembentukan tingkah laku siswa.

5. Diharapakan kepada guru PPKn agar tetap sabar walaupun ada berbagai kendala yang dihadapi dalam membentuk tingkah laku siswa.

6. Diharapan kepada guru PPKn agar tetap semagat untuk mencari solusi memecahkan masalah dengan baik.

\section{UCAPAN TERIMA KASIH}

Penulis mengucapkan terima kasih kepada Universitas Muhammadiayah Mataram yang senantiasa memberikan dukungan anaggaran dana penelitian kepada penulis sehingga artikel ilimiah ini selesai dengan baik.

\section{DAFTAR RUJUKAN}

[1] R. Indonesia, "Undang-undang Republik Indonesia Nomor 20 tahun 2003 tentang Sistem Pendidikan Nasional," Jakarta Pemerintah Republik Indones., 2003.

[2] A. Syarbini, Model Pendidikan Karakter Dalam Keluarga. Elex Media Komputindo, 2014.

[3] F. Fitriani and A. Sakban, "Penerapan Pendidikan Karakter Terhadap Efektifitas Penggunaan Kurikulum 2013 Dalam Persepektif Moral Bangsa di SMA Nurul Jannah NW Ampenan," Civ. Pendidikan-Penelitian-Pengabdian Pendidik. Pancasila dan Kewarganegaraan, vol. 6, no. 1, pp. 1-7, 2018.

[4] S. B. Raharjo, "Pendidikan Karakter Sebagai Upaya Menciptakan Akhlak Mulia,” J. Pendidik. dan Kebud., vol. 16, no. 3, pp. 229-238, 2010.

[5] F. Y. Fauzi, I. Arianto, and E. Solihatin, "Peran Guru Pendidikan Pancasila Dan Kewarganegaraan Dalam Upaya Pembentukan Karakter Peserta Didik,” J. PPKN UNJ Online,(Online), vol. 1, no. 2, 2013.

[6] D. Sugiyono, "Metode penelitian kuantitatif kualitatif dan R dan D," Alf. Bandung, 2010.

[7] M. Ali, "Strategi Penelitian Pendidikan Statistik Bandung," Bumi Aksara, 1993.

[8] A. Suharsimi, "Prosedur Penelitian, Jakarta: PT," Rineka Cipta, p. 201:274, 2013.

[9] Sugiyono, "Memahami Penelitian Kualitatif," Bandung Alf., 2005.

[10] A. Soebani and B. Ahmad, "Metode Penelitian Kualitatif," Bandung, Pustaka Setia, 2012.

[11] M. B. Miles and A. M. Huberman, Analisis Data Kualitatif. Terjemahan Tjetjep Rohendi Rohidi. 1992. 